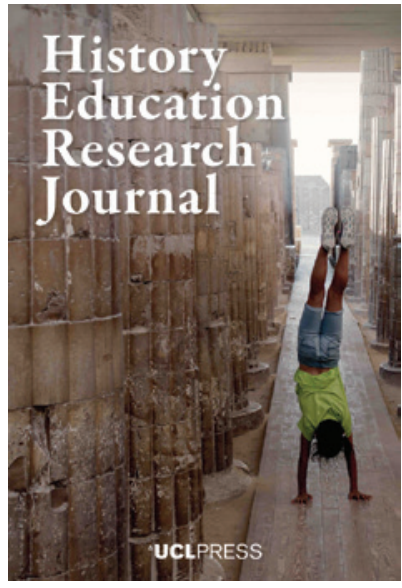

${ }^{\Perp}$ UCLPRESS

HISTORY EDUCATION RESEARCH JOURNAL

ISSN 2631-9713 (Online)

Journal homepage:

https://www.uclpress.co.uk/pages/history-educationresearch-journal

\title{
How younger students perceive and identify historical significance
}

\section{Karin Bergman (iD}

\section{How to cite this article}

Bergman, K. (2020) 'How younger students perceive and identify historical significance'. History Education Research Journal, 17 (2), 164-78. Online. https://doi. org/10.14324/HERJ.17.2.03

Submission date: 5 September 2019

Acceptance date: 15 June 2020

Publication date: 20 October 2020

\section{Peer review}

This article has been peer reviewed through the journal's standard double-blind peer review, where both the reviewers and authors are anonymized during review.

\section{Copyright}

(C) 2020 Bergman. This is an open-access article distributed under the terms of the Creative Commons Attribution Licence (CC BY) 4.0 https://creativecommons.org/licenses/by/4.0/, which permits unrestricted use, distribution and reproduction in any medium, provided the original author and source are credited.

\section{Open access}

The History Education Research Journal is a peer-reviewed open-access journal. 


\title{
How younger students perceive and identify historical significance
}

\author{
Karin Bergman* - Mälardalens University, Sweden
}

\begin{abstract}
Historical significance is a historical thinking concept. Being able to identify historical significance is viewed as important for understanding change and continuity in the past, and for understanding the way 'history' is constructed by present society. This article discusses how Swedish students in Grade 5 (age 11 years) perceive and understand historical significance without having received prior instruction on how to identify historical significance. The results show that the students see thrilling and exciting events in the past as significant, as well as the events, inventions, ideas and values that have influenced the present or changed the course of history in some way. In this paper, I compare students' answers to definitions of historical significance formulated by Christine Counsell (2004) and Matthew Bradshaw (2006). For the study, 67 students were interviewed in semi-structured interviews in small groups. They attended six different schools in the middle part of Sweden and came from varying backgrounds. Regardless of their backgrounds or origins, the students see the history culture of the majority, as presented in their history education, as their own.
\end{abstract}

Keywords: history as school subject; historical significance; historical thinking; younger students

\section{Introduction}

What is historical significance? Historical significance is defined here as one of the ways in which history is separated from the past. In order to study any part of the past, the past needs to be organized, usually in a narrative form, and what to study needs to be selected. History is also a cultural construction, and students' understanding of historical significance is a part of that construct (Ricoeur, 1985; Lee et al., 2001; Rüsen, 2004, 2005, 2017; Parkes, 2019).

Understanding how students define what they see as important in the past provides insight into the way that students construct history. Students' definitions of historical significance indicate how they understand history and how they think history is defined and constructed. The way students define and understand history affects the way they learn history and what they learn about history. There seems to be an interplay between what students learn at home and what they learn at school; students incorporate their own experiences with the history they encounter into history as a school subject (Terizan and Yeager, 2007; Hawkey and Prior, 2011). If the school fails to address students' understanding regarding significance in history, history as a school subject might seem irrelevant to students, or even untrustworthy (Wertsch, 2000; Nordgren, 2006; Terizan and Yeager, 2007; Hawkey and Prior, 2011). Understanding students' perceptions and understandings of historical significance is crucial for history 
education: 'Conceptions of significance are at the heart of all history - and history education - and research on the development of students' ideas about the topic may provide insight into their overall frameworks for historical understanding' (Barton, 2005: 9).

The ability to identify historical significance is a necessary part of historical thinking. It is defined as the ability to identify the events or changes in the past that are important to study, and the ability to understand how one's own perceptions of history have been formed, how history is reproduced in society and in the teaching of history as a school subject, and how history is selected and presented (Seixas, 1994, 2017). According to Lévesque (2008), without the ability to identify historical significance, studies of the past are meaningless.

Counsell (2011) writes that it is important to determine what kind of thinking students use when they identify historical significance. She agrees with Wineburg (2001) that this way of thinking may not come naturally for students. This paper provides some examples of the way Swedish students identify historical significance without having received prior instruction on the matter. It aims to illuminate the way students naturally - so to speak, borrowing from Wineburg (ibid.) - reason about historical significance. The ability to identify historical significance is viewed as important for understanding change and continuity in the past, and for understanding the way 'history' is constructed by present society. In short, the ability to identify historical significance is viewed as necessary for thinking historically. The overarching aim of this article is to determine if this aspect of thinking historically is formulated by students when they talk about history, or if historical thinking is an unnatural act, as Wineburg (ibid.) puts it.

First, I will define historical significance as it is used and understood in this article. Then the methodology of the study will be described. The results section presents the different definitions and understandings that the students had of historical significance. The discussion is focused on the students' definitions in comparison with those provided in the literature discussed below, and how the students' definitions provide insight into their understanding of historical significance.

\section{Historical significance}

Historical significance is a historical thinking concept. Historical thinking as theory and practice has been accepted for some time in the field of history education in most Anglo-Saxon countries, as well as in the Nordic countries together with concepts from the German tradition (Sandahl, 2015; Seixas, 2017). Historical significance is one of the concepts found in the historical thinking model as proposed, among others, by Seixas (1994; see also Lee, 1983; Wineburg, 2001), and the ability to identify historical significance is viewed as necessary in order to engage in historical thinking. Wineburg (1991) believes that the ability to think historically gives a spatial and contemporary context to history. According to Seixas (2017: 598; see also Seixas and Morton, 2013), the ability to think historically comprises the following abilities, or skills: establishing historical significance, using primary source evidence, identifying continuity and change, analysing cause and consequence, historical perspective taking, and understanding the ethical dimensions of history. (For a discussion of these, see Thorp and Persson, 2020.) To master historical thinking, the six skills, or second-order concepts, must be used when encountering the present and using the past to understand the present. Based on Piaget's studies (1976), it was long thought that children younger than highschool age were unable to use the skills that are part of historical thinking. Children were thought to lack the required intellectual maturity. That view was questioned, 
and later studies showed that both older and younger students can use the skills linked to historical thinking - that it is a matter of teaching students to use them, not a matter of intellectual maturity (Booth, 1980; Levstik, 2000).

There is a difference between historical significance for a nation, for example, and historical significance for an individual. A label of significance can also be based on the notion that history can help us understand and orient ourselves in our present time. What is significant in history depends, then, on what we want to investigate in the present (Seixas and Morton, 2013). Counsell (2004: 34) has developed a model containing five criteria that she thinks can be seen as universally significant, without the use of presentism (see also Seixas and Morton, 2013):

Remarkable - the event/development was remarked upon by people at the time and/or since

Remembered - the event/development was important at some stage in history within the collective memory of a group or groups

Resonant - people like to make analogies with it; it is possible to connect it with experiences, beliefs or situations across time and space

Results in change - it had consequences for the future

Revealing - of some other aspect of the past.

Counsell (2004) also discusses what should not be regarded as historically significant. She believes that it is wrong to equate many people having been affected or influenced by an event with historical significance, which would lead to purely quantitative criteria for historical significance, rather than a qualitative approach. In her definition of historical significance, the number of people involved has little or nothing to do with the significance of the event. The same holds true for the duration of an event: a longlasting event is not necessarily more significant than a brief one. A long war is not necessarily more significant than a short one. The Six-Day War, for example, resulted in thousands of casualties and had a huge impact on the region and the people who lived there.

Another widely shared example of a definition of historical significance is the acronym GREAT, formulated by Bradshaw (2006: 21):

Groundbreaking and stunning change (Changes in technology, new weapons and tactics. Could also be new life experiences, roles, responsibilities and jobs).

Remembered by all (An event which, or person who, is nationally remembered, maybe even studied by schools; appears in stories/films).

Events that were far reaching (An event which, or person who, touched the whole globe, or at least a large part of it).

Affecting the future (An event which, or person who, had as much effect on people after it had finished as at the time on their lives and on society as a whole).

Terrifying (An event or person remembered because it is so dreadful and it is so large and scary it is hard to even imagine).

Counsell (2004) and Bradshaw (2006) emphasize an event's impact on both the present and the future, as well as an event becoming part of the collective memory in one way or another. Their definitions of change in the past differ, however. Counsell (2004) emphasizes changes in the past that affect or affected the future, but Bradshaw (2006) identifies changes solely in the past. Bradshaw (ibid.) also includes the criterion that an event must be far reaching to be deemed historically significant. It could be argued 
that this criterion resembles Counsell's (2004) criteria of remembered and resonant, but Bradshaw's (2006) perspective of the event places more emphasis on the way the event is remembered and used in the present. Affecting the future, which Bradshaw (ibid.) uses, only defines it as a direct effect on the future. Bradshaw (ibid.) appears to place more emphasis on the quantitative aspect than Counsell (2004) does. Minority groups and their experiences can be seen as being excluded in the criterion remembered by all. Remarkable, which Counsell (ibid.) uses, can also be used in a positive sense, which cannot be said about terrifying, used by Bradshaw (2006). Together, these two definitions give a general definition of historical significance that will be used in this study as a model to compare with the students' definitions of historical significance. Both models are used to identify the students' uses of historical significance. To structure the comparison, I first looked at Counsell's (2004) criteria, and then at Bradshaw's (2006).

\section{Earlier research}

Previous studies have mainly focused on how to teach historical significance. Teaching historical significance has been seen as a way to explain the chosen content in history teaching to students, and as a way to help them see the context and the continuity of the events they study (Metzger, 2010). There have been few case studies about historical significance, and those carried out have primarily looked at different minority groups and how they formulate historical significance (Barton and Levstik, 1998; Barton, 2005; Terizan and Yeager, 2007; Hawkey and Prior, 2011; Kim, 2018). The studies make several connections between students' identifications of historical significance and students' formation of their own identities (Rosenzweig and Thelen, 1998; Barton and Levstik, 1998; Létourneau and Moisan, 2004; Barton and McCully, 2012).

Earlier research has also mainly studied older students or adults, and the link between a historical 'we' and what is labelled as being historically significant is evident. The events that are regarded as important for the group with which a person identifies are seen by that person as historically significant (Levstik, 2000; Sandberg, 2018). Historical significance has also been discussed in other studies. Barton and Levstik (1998) conducted a study that has a close resemblance to my study. They interviewed students in the US in Grades 5 to 8 . The students mainly viewed the processes of gaining opportunities and freedom as being significant in US history. Barton and Levstik (ibid.) also emphasize schooling as an important factor in forming a public commemoration of what society considers to be significant. The present study is rare in that its participants are younger students - age 11 years - and students with varying backgrounds. It also differs from earlier studies in that the students are not presented with materials, pictures or artefacts to steer the discussion, as in other studies (Levstik and Barton, 2011; Rudnert, 2019). The way younger students understand and formulate history in a wider definition has been the focus of a few recent studies, but those studies primarily use historical consciousness as a theoretical framework. In those studies, the students see history as the big events in the past, male driven, violent, but also entertaining (Stymne, 2017; Sandberg, 2018; Rudnert, 2019).

\section{Method}

For this paper, 67 students in Grade 5 (11 years old) were interviewed in spring 2016. Most of the interviews were conducted in pairs, or in groups of three. Two interviews were conducted with groups of five students, and two were conducted with only 
one student. The interviews in the larger groups were somewhat unruly, and the students sometimes needed to repeat themselves to be heard, but the interviews with one student did not differ from the interviews with the students in pairs or groups of three in the way they were conducted or in the type of information that was gathered. The students attended six schools in three municipalities across Sweden. The schools are located in the middle part of Sweden, and they range from a school in a very wealthy urban area to a rural school in a small community, to a school in a neighbourhood where more than half of the inhabitants are first- or second-generation immigrants. The other three schools were situated in middle-class areas, two urban and one rural. The students predominantly lived fairly close to the schools, which made it possible to include a variable for the students' socio-economic backgrounds. The assumption before the study was that the differences in backgrounds, including socio-economic backgrounds, would be visible in the empirical material; however, the students gave similar answers irrespective of their backgrounds. Therefore, no comparisons between the schools, or between the students based on the schools they attended, will be presented.

The interviews were held in different places within the schools, at times chosen by the teachers. The interviews lasted between half an hour and three-quarters of an hour. The longer interviews were with the larger groups of students. The interviews with one student took around the same amount of time as the interviews with two or three students.

The students in the study were asked what events or developments they thought were significant in the past, and how those events or developments are identified and selected. The students reflected about history as phenomena, and how and by whom history as a school subject and its contents are defined and selected. The term 'historical significance' was not used in the interviews; rather, the students were asked to identify what they saw as important in the past, as well as how, and by whom, what they believed is regarded as history is constructed. The focus is on the way in which the students expressed historical significance in the interviews, and what in the past the students labelled as being important and why they thought it was important.

The interviews were recorded and then transcribed. The researcher listened to the interviews multiple times before transcribing them. Following the transcription, the researcher looked for key words and utterances that could be related to the students' views about significance in the past. Based on those key words and utterances, categories were formed (Kvale and Brinkmann, 2014). The researcher identified what the students thought was significant; the students did not use the term 'significant' themselves. The categories were then related to Counsell's (2004) and Bradshaw's (2006) definitions of historical significance. A comparison between the categories based on the students' answers and the definitions above was then carried out. The results should be regarded as empirical data from the field, and any wider generalizations from these findings should be made with great caution; however, the findings are not to be regarded as atypical, but rather as representative, of Swedish students in the given age group.

\section{What is significant?}

This paper first concentrates on what aspects of the past the students label as historically significant, and how they reason about and perceive historical significance. What the students define as historically significant are the dramatic parts of history - the events that they see as changes in history, and events in the past that affect the present. 


\section{Dramatic history}

'Thrilling' seems to be the key word when the students described historical significance. The students treated history as an interesting story that is even more exciting because the events are not fictional but have really happened. The students singled out the bloody and the dramatic as especially interesting to study:

(2:3:1) Yes, it feels like it was more violent before than it is now, so in that way, it will be a bit more exciting. (School 2, Interview 3)

$(1: 1: 1)$ The Viking era was exciting because they found many tombs.

(1:1:2) Yes, and this bloodbath. I like scary stuff. (School 1, Interview 1)

(3:4:1) Because I like ...

(3:4:2) You like wars.

(3:4:1) I think it is interesting.

(3:4:2) I think so too, how it was at the concentration camps and such.

$(3: 4: 1)$ I have played many games about it, so I find it interesting. It is interesting since it is terrible.

(3:4:2) It is like, scary terrible. (School 3, Interview 4)

One event that was identified as being especially interesting was the Stockholm Bloodbath, which most of the students had recently studied. The Second World War was also frequently mentioned as an important event in history because it was a dramatic event.

In their descriptions of dramatic events in history, the students emphasize the number of people who died as a key element in measuring the significance of an event in the past. Other formulations that the students used included '[it] affected many people', although the students did not further specify what they meant by 'affected'. There were also discussions by the students regarding the number of deaths required for the deaths to be regarded as significant in history. One death was not enough, with the exception of the deaths of famous people. The deaths also needed to be violent in some way. The students gave examples of what they think is significant or not in history:

(4:2:1) Whether one person dies by being speared or 170 die by being speared.

(4:2:2) Or the plague, if one gets the plague and then nobody gets it ... but if many.

(4:2:1) For example, Ebola, though they have managed it now.

(4:2:2) But if there were many who got the plague, it would be a little bigger story that you would talk about in school.

(4:2:1) I think it is the big events that affect many people they choose to talk about in school. (School 4, Interview 2)

Numbers are a frequent aspect of students' answers: the more people affected, the more significant the event is considered to be. The students see the Second World War as significant because it 'affected many people' and 'a lot of people died'. In other words, sheer numbers are important to the students. Other words they use to describe a historically significant event are 'big' or 'widespread'.

History, in this context, is treated as entertainment. The exciting parts are especially emphasized, since the students talk about the fact that they can always find out more about a historical event - that what it is possible to know is unlimited, as some students put it:

(1:1:3) In math, it is 5 times 5 equals 25 , but in history there is always more to develop; you can always know more about them [the people of the past], how many were there. (School 1, Interview 1) 
Closely related to the notion that history is thrilling and exciting is history as fiction. The students do not seem to draw a definite line between history as fiction and history as 'science'. The students mention documentaries about historical events, and films with a historical setting, such as Titanic, as sources of knowledge about historical times and events. 'Events' are also frequently mentioned when the students define what is important in history.

Also linked to dramatic history is the significance that the students ascribe to an event or people because they are widely known. The fact that Gustav Vasa, a sixteenthcentury king of Sweden, was famous is regarded in one interview as a good enough reason to study him in history as a school subject. 'Widely known' is also put forward as a reason to study the Second World War; it is something that the students believe 'everybody' should know about. When the students reason about the significance of events and actors, they mention that they are significant because many people know and still talk about them today.

Dramatic history is also visible in the individual interests that students have in particular periods or events in history. One student mentions, for example, that she is interested in ancient Egypt, and some students talk about a fascination for the Stone Age. In these examples, the students regard not the periods or events in themselves, but rather their own interests - based on things such as finding the period or event entertaining or mysterious - as the main reason for the significance of those periods or events. As mentioned earlier, their own emotions, mostly involving the things they see as exciting or entertaining, seem to be linked to the periods they view as important and to the periods they see as being vital to learn about. None of the children cited their own ethnicities, or cultural or religious backgrounds, as grounds for an interest in history.

The impact of an event on the surrounding society is also a factor when the students reason about what is significant in the past. The students argue that what is in the news today will be history in the future.

\section{Events that changed history}

Another factor for historical significance identified by the students is that the event in the past somehow changed history. In the historical events described by the students as being significant, they usually mention an individual who developed a new idea or invention, and that the idea or invention somehow changed history and therefore the present. The most common example given by the students of an event that changed history is the Stockholm Bloodbath because, according to them, it led to the uprisings led by Gustav Vasa, which resulted, as the students formulated it, in Sweden being liberated from Denmark:

(Researcher) Who says that this is important, that all children should read about this?

(2:4:1) No one says so, but you understand.

(2:4:1) It's kind of Pernilla [their teacher] who says that's what we'll read about and learn.

(2:4:2) Like Stockholm's Bloodbath. It was an important event, otherwise Denmark might have been in control of us today.

(2:4:1) Then we might, we would be speaking Danish in this interview.

(2:4:2) But everyone has somehow agreed, like: this is history; this is important. (School 2, Interview 4) 
The students also touch upon the opinion that what is significant in the past is something that is agreed upon by the community, as discussed below. In the students' descriptions, the events that changed history are driven by individuals, such as Gustav Vasa in the example above:

(6:2:2) But if a certain person hadn't done that, things wouldn't be as they are now.

(6.2:1) Like Martin Luther, like he did.

(6:2:2) Unless, if he hadn't nailed up those 95 theses, and then the Protestant variant of Christianity hadn't emerged, we would be Catholics right now. $\ldots$

(6:2:2) What was done affected what is happening right now. (School 6, Interview 2)

In the earlier example, the male actors of the events are in the foreground. The events are regarded by the students as being driven by these actors, and when the students talk about past events, they only mention males. Things connected to everyday life, such as women's chores, are pointed out as being especially insignificant. In one interview, the students talk about what is important enough in history to be included in the history textbooks:

(4:1:2) But everything that happened before is not in the textbooks. It's not 'they went up and ate breakfast and went out and took care of the cows' that's not written in the books.

(4:1:1) They write about what is exciting.

$(4: 1: 3) \ldots$ and what's interesting. (School 4 , Interview 1)

One aspect that the students set as a criterion for something being important is that it is 'known'. The students reason that a collective 'we' has decided what is to be viewed as significant. The students do not believe that they have any influence on what is considered to be significant in the past or the present; they believe that it is decided by someone else. The significant events of the past are viewed as something that everybody should simply know. In these reflections, the students often define an event in the past as being significant based on the fact that a lot of people know about it, and they express that it is important to have knowledge of such things to be able to interact in a common society:

(2:3:2) In order for everyone to learn the same things so that it does not get weird; we would learn about World War II, while some others would learn about the French Revolution.

(2:3:1) Yes, that would be strange.

(Researcher) Why would it be strange?

(2:3:2) Because then they would not know anything about what we were talking about, and we would not know anything about what they were talking about.

(2:3:1) I also think they have chosen this way [to teach] so you don't learn wrong, unnecessary things.

(2:3:3) Yes.

(2:3:1) For example, someone opens a door and there are chairs there, and, oh, they have never seen chairs before. Maybe it's just not necessary to know, but it's more necessary to know a bit about medieval times and so on. 
(2:3:2) Yes, just that they choose what's important ...

(2:3:3) World War II, French Revolution.

(Researcher) Why are they important?

(2:3:3) Because there was war. There was a huge war, and many people know what the Second World War is, so we should know that, too. (School 2, Interview 3)

From the students' perspective, changes in history are driven by individual males whose actions have had a direct impact on society today. Furthermore, the students consider history to consist of the important events in the past. In their minds, the collective decides what events are seen as important, and what is remembered is also what is important for the students to learn.

\section{Events in the past upon which the present builds}

The discussion about Martin Luther (from School 6, Interview 2) also provides an example of how past ideas and inventions are labelled by the students as significant based upon the fact that they affect the present. The students seem to believe that Luther nailing up the theses led directly to the result that they are Protestant today, and that this was a good thing. People's ideas and actions in the past are regarded as the driving forces behind the events and ideas of the past and the present. This is also considered to be the case when it comes to ideas of equality, such as all people being equal. One example given is that Abraham Lincoln abolished slavery, and therefore people who live now know that all people are equal. According to the students, what is right and wrong is taught, since they study the mischief or mistakes people made in the past. The most common example the students give is that by studying history they will learn that it is wrong to kill, since they see killing as something that was common in past times, but that people in the present have learned that it is wrong by studying events in the past. According to the students, the mission of history as a school subject is to teach students so that they can learn from mistakes made in the past. It is worth mentioning that using history as a counterexample of how to be a good citizen is not mentioned in the curricula for history as a school subject; however, we do not know how teachers address the matter. The interpretation of the students in the interviews is that they should learn from mistakes in the past:

I feel that history is quite important because, thanks to history, we also know what the consequences of some things are, and that is good. Nobel's brother died when they were handling dynamite, and so we know it's dangerous. If we didn't know, then we might stand around some dynamite, and it could explode and we'd die or something, so it's important. (Student 1, School 2, Interview 1)

As well as learning from bad behaviour, another reason that the students mention for having history as a school subject is learning from good examples, especially morally good examples.

Other events or occurrences in the past are seen by the students as being significant because they believe knowledge of them can help them deal with similar situations in the future. The most common example the students give is that they know what to do if there is a new outbreak of the plague because they have studied the Black Death.

One other thing the participants put forward as significant in the past is practical knowledge in different occupations. Practical knowledge based on the previous 
experiences of others provides a knowledge base for those occupations. Examples of practical knowledge that the students give include what medicines to give to sick animals and how to repair engines.

Inventions are also labelled by the students as being significant in the past, based on the fact that the inventions have shaped the present. The students give examples such as the invention of written language, which made other inventions such as the telephone possible. Another example is the discovery of fire, which the students believe gave way to electricity. These inventions are regarded as significant because, according to the students, they have shaped the present to a large extent. The students also consider the telephone, or even the iPhone, as a fundamental invention for the society in which they live. The students regard technical development in history as being important. The students often see one individual's actions, or one event or one invention, as a change in history. Technical development is also regarded by the students as a continuity with the past.

The historical thinking concept of cause and effect was not mentioned by the students other than implicitly, as in the example above, where mobile phones are seen as a necessity for present society. The students talk to a larger extent about direct causes and changes.

\section{Discussion}

How do students identify historical significance without prior instruction in, and definitions of, historical significance? Knowledge about whether, and how, students identify historical significance provides an insight into how students understand and perceive the past, and history as a school subject.

The students use the term 'important' in the interviews to identify historical significance. The things that the students consider to be important are mainly those that they describe as the big events of the past. The big events, according to the students, mostly coincide with dramatic events in the past. In the students' descriptions, these events are mostly driven by male actors. The will and the ideas of individuals are considered to be the driving force in the past. Groups of people - such as nations, religious cults, or people belonging to a specific ethnicity or culture - are not mentioned as a driving force in the past. In that, and in other ways, the students follow the national narrative of individual heroes and villains, concentrating on the political history that is significant for the majority culture (Åström Elmersjö, 2013). In the students' definitions of the significant in the past, there is also a clear dichotomy between good and bad, and between failure and success (see also Kim, 2018). The fight between right and wrong is part of the narrative that the students construct about the past, and it also serves as an illustration of continuity in history, as the students said they could learn from the good and bad examples of the past.

The students seem to consider what is significant as being equivalent to what they should study in history as a school subject. However, they also emphasize the practical uses that they could have for historical knowledge. What is significant is also what is useful. The practical knowledge that the students mention is mainly concerned with actions such as isolating the sick in the case of an outbreak of plague, or knowhow linked to different professions - knowledge that is not usually part of the teaching of history as a school subject.

The students' descriptions of what they believe is important in the past were analysed by comparing them with Counsell's (2004) and Bradshaw's (2006) definitions of historical significance. The students' utterances were compared with the definitions 
to see if they would fit within those definitions of historical significance. In the comparison, both similarities and differences can be noted. The students emphasize numbers: the number of people affected determines the significance of an event; that is, the students have a quantitative approach to historical significance. Neither Counsell (2004) nor Bradshaw (2006) have numbers as a criterion; their approaches are more qualitative. Death tolls are nevertheless seen as important in the students' views of historical significance, as noted in earlier studies (Kim, 2018). It could also be argued that high death tolls fit Bradshaw's (2006) criterion of terrifying.

Numbers are used in Counsell's (2004) and Bradshaw's (2006) criteria of far reaching and terrifying: an event in the past that affected many people is likely to be remarkable, remembered, resonant and far reaching. The students emphasize the thrilling parts of the past; those parts are entertaining and exciting, and they are therefore seen as being significant. This aspect is missing in the criteria put forward by Counsell (2004) and Bradshaw (2006), although Bradshaw does list terrifying as a criterion for historical significance. The Second World War, which was labelled as a significant event by the students, can be seen as an event fulfilling all of Counsell's (2004) and Bradshaw's (2006) criteria for historical significance: the war was terrible in so many ways - it affected many people, it is widely known about, and many analogies have been made to the events and individuals connected to the war. The Second World War is also an event that is widely known in society, and it can therefore be assumed to be an event that the students have come across in society as being something important. They have accepted what society sees as historical significance as their own definition of significance. In addition to the criteria of Counsell's (2004) and Bradshaw's (2006) models, the students see shared knowledge as practical in the sense that it is easier to communicate when there is a mutual frame of reference (see also Ledman, 2015). The students see the Second World War as significant also due to their interest in events that involve a lot of action.

The students seem to regard their own time, the present, as being complete, and the past as just the past. They believe that events of the present will be regarded in the future as significant events, but they do not think events that lie further back in time will affect the future; that is, events of the past cannot make a 'comeback', so to speak, to affect the future.

Students' emphasis on tragic events in the past is also noted in earlier research. The hardships of wars and other past tragedies were mentioned as significant based on the tragic nature of the events, but other definitions of significant were not mentioned by respondents in previous research (Kim, 2018).

The students in this study, and in those of Counsell (2004) and Bradshaw (2006), suggest that if an event results in change, the event is important or historically significant. The students regard individuals in the past as the driving force behind changes in the past. These actors either altered the chain of events through their actions or their formulations of new ideas, or they changed ideals and norms through their new ideas. In all the examples given by the students, individuals lie behind changes for the better.

The ability to identify or distinguish historical significance as part of the ability to think historically is closely linked to other aspects of historical thinking skills, such as identifying change and continuity. As a historical thinking skill, the ability to identify change and continuity includes the ability to see how the past and the present follow the lines of what changes and what remains the same. Students should be able to see long-term changes and be able to understand the difference between a change and an event. This skill is complicated by the fact that events can lead to changes, which means that the boundary between an event and a change is not always self-evident 
(Lee, 1996). The students in the study do identify change in the past. They also see continuity as a part of what is significant in history, in that they see events and inventions upon which the present builds as being significant. According to the students, changes in the past are initiated and driven by individuals in the past. The students identify continuity when they consider the ways they believe different technological inventions build upon each other. However, the students do not identify or address cause and effect, other than implicitly. Rather, they mention direct consequences mainly something they believe they can learn from in their lives. The students propose a direct form of causality between events in the past and the present. This implies that they do not have the big picture of the past. They do not seem to have any insight into the complexity of cause and effect in history, nor do they seem to understand that the way history is viewed depends on one's perspective. This should not be considered a criticism of the students, but rather an indication of where the students are in their development of historical thinking.

Some of Counsell's (2004) and Bradshaw's (2006) criteria are not found in the students' reasoning about historical significance. Revealing, one of Counsell's (2004) suggested criteria, is not mentioned, for example. For the students, history is a fixed story; revealing something about the past is only possible if new sources are found. Resonant is another criterion that is not found in the interviews. The students do believe they can learn from the past, and they do seem to feel some kind of connection with the people of the past. Result in change is mentioned by the students, as discussed above. The students see the changes as having a direct impact on the present, and they see the changes as the result of individual actions. Bradshaw's (2006) affecting the future is also close to the students' definition, but his criterion emphasizes the direct future after the event, whereas the students' definitions, as mentioned, emphasize the present as the future of the event. The students' definition is close to Bradshaw's (ibid.) definition groundbreaking and stunning change, as it does consider change as being driven by individuals in the past. The students see rememberedthat something is 'known' - as a criterion for historical significance, and both Counsell (2004) and Bradshaw (2006) include remembered as a criterion. Events that were far reaching is mentioned by the students, as they speak about events that affected a large number of people as being important events. Remarkable is also visible in the students' reasonings about historical significance, as the students emphasize that everyday life is not historically significant.

The students' emphases are on the number of people affected, the narrative aspects of the past, and the links to the present - emphases that might not be found to be equally strong under Counsell (2004) or Bradshaw (2006). As mentioned above, terrifying is the most visible of Counsell's (2004) and Bradshaw's (2006) criteria present in the empirical data. However, the entertaining aspect - the thrilling aspect - that the students mention is not represented in Counsell's (2004) or Bradshaw's (2006) definitions. As pointed out in the introduction, the students have not been introduced to the concept of historical significance, and their definitions focus on their own uses of history - that is, to aid their understanding of their contemporary society and to enjoy history as an exciting narrative.

Based on the interviews, it can be said that the students mainly understand history as political history, and also as male history. It is the public events that the students consider important. Everyday life is considered less important. Thus, women are completely invisible in the narrative the students construct of the past, which previous studies have also noted (Kim, 2018). The students mainly stress that it is the so-called big events in history that are important. The thrilling and the bloody 
aspects of history are also important factors in the students' reasoning about historical significance. The big events and the male emphasis in the students' answers mirror a majority history culture that the students encounter in the teaching of history as a school subject. The students also almost exclusively mention events in Swedish history, further underpinning the view that the history of the majority is the significant history (Seixas, 1994; Terizan and Yeager, 2007). This majority history also confronts the students in society and through, for example, popular culture (Seixas, 1994; Wineburg, 2001). Earlier research has shown that students who do not identify with the majority culture formulate a different narrative, a narrative in which the national narrative includes the hardships of their own group (Levstik, 2008). However, all students in this study seem to consider the majority culture as their own, regardless of their gender, background or other group identity. This might be explained by the students' age - at 10 or 11 years old, they have not yet been forced to formulate an excluding we. They can formulate an inclusive we, and in school they use the we of the majority culture and the we linked to other group identities simultaneously. Teaching an inclusive we is not included in school curricula, but neither is its opposite - singling out students as belonging to different groups. The inclusive we can be seen as one way of teaching for a shared society to which the students feel connection and loyalty (Sandberg, 2018). Notably, we is commonly used in references to the past, a habit that may have influenced the students.

\section{Conclusion}

The students in the study emphasize war and ideas in the past as being significant, as has been shown in earlier studies (Terizan and Yeager, 2007). In the students' responses, the great men of the past, and the thrilling, entertaining parts of the past, are viewed as significant. The changes in the past, notably those for the better, are also apparent in the interviews, and this has also been noted in earlier studies (Barton and Levstik, 1998; VanSledright, 2002). The idea of history as a constant movement from bad to better is evident in the students' responses. Wineburg (2001) writes that this seems to be the instinctive way of understanding history.

Historical thinking is, as Wineburg (ibid.) puts it, an unnatural act. The point of investigating how students reason about historical significance without any prior instruction in historical significance is to show how students formulate, or identify, historical significance without any instruction. The students try to form an understanding of the teaching of history as a school subject. They also try to form an understanding of the history they encounter outside school. The students do have historical thinking skills, but they need to put them into context, and they need teaching in order to understand the significance of the events that they label interesting and exciting.

\section{Notes on the contributor}

Karin Bergman is a senior lecturer at Mälardalens University, Sweden. Her PhD thesis, completed in 2018, was 'To learn from the past: Younger students' understanding of and motivation for history as a school subject'. Her research interests concern students' understandings of history as a school subject, and museum teaching material. She is involved in a project to study how various curricula express the values that teachers should possess. She teaches didactics, pedagogy, history, history didactics and vocational training. 


\section{References}

Åström Elmersjö, H. (2013) Norden, nationen och historien: perspektiv på föreningarna Nordens historieläroboksrevision 1919-1972. Lund: Nordic Academic Press.

Barton, K.C. (2005) '“Best not to forget them": Secondary students' judgment of historical significance in Northern Ireland'. Theory and Research in Social Education, 33 (1), 9-44. Online. https://doi.org/10.1080/00933104.2005.10473270

Barton, K.C. and Levstik, L.S. (1998) " "It wasn't a good part of history": National identity and students' explanation of historical significance'. Teachers College Record, 99 (3), 478-513.

Barton, K.C. and McCully, A.W. (2012) 'Trying to "see things differently": Northern Ireland students' struggle to understand alternative historical perspectives'. Theory and Research in Social Education, 40 (4), 371-408. Online. https://doi.org/10.1080/00933104.2012.710928

Booth, M. (1980) 'A modern world history course and the thinking of adolescent students'. Educational Review, 32 (3), 245-57. Online. https://doi.org/10.1080/0013191800320302

Bradshaw, M. (2006) 'Creating controversy in the classroom: Making progress with historical significance'. Teaching History, 125, 18-25.

Counsell, C. (2004) 'Looking through a Josephine-Butler-shaped window: Focusing students' thinking on historical significance'. Teaching History, 114, 30-6.

Counsell, C. (2011) 'What do we want students to do with historical change and continuity?' In Davies, I. (ed.) Debates in History Teaching. 1st ed. New York: Routledge, 109-23.

Hawkey, K. and Prior, J. (2011) 'History, memory cultures and meaning in the classroom'. Journal of Curriculum Studies, 43 (2), 231-47. Online. https://doi.org/10.1080/00220272.2010.516022

Kim, G. (2018) 'Holding the severed finger: Korean students' understanding of historical significance'. Journal of Curriculum Studies, 50 (4), 508-34. Online. https://doi.org/10.1080/00220 272.2018.1461934

Kvale, S. and Brinkmann, S. (2014) Den kvalitativa forskningsintervjun. 3rd ed. Lund: Studentlitteratur.

Ledman, K. (2015) '"Så man kan vara med": om historieundervisningens värde och mening enligt elever på yrkesprogram'. Utbildning och Demokrati, 24 (3).

Lee, P.J. (1983) 'History teaching and philosophy of history', History and Theory, 22 (4), 19-49. Online. https://doi.org/10.2307/2505214

Lee, P.J. (1996) 'None of us was there: Children's ideas about why historical accounts differ'. In Ahonen, S. (ed.) Nordisk konferens om historiedidaktik Historiedidaktik i Norden 6: historiemedvetandet - teori og praksis. Copenhagen: Institut for historie og samfundsfag, Danmarks Lærerhøjskole, 23-58.

Lee, P.J., Dickinson, A. and Ashhy, R. (2001) 'Children's ideas about historical explanation'. In Dickinson, A.K., Gordon, P. and Lee, P.J. (eds) International Review of History Education. Vol. 3: Raising Standards in History Education. London: Woburn Press, 97-115.

Létourneau, J. and Moisan, S. (2004) 'Young people's assimilation of a collective historical memory: A case study of Quebeckers of French-Canadian heritage. In Seixas, P. (ed.) Theorizing Historical Consciousness. Toronto: University of Toronto Press, 109-28.

Lévesque, S. (2008) Thinking Historically: Educating students for the twenty-first century. Toronto: University of Toronto Press.

Levstik, L.S. (2000) 'Articulating the silences: Teachers' and adolescents' conceptions of historical significance'. In Stearns, P.N., Seixas, P. and Wineburg, S. (eds) Knowing, Teaching, and Learning History: National and international perspectives. New York: New York University Press, 284-305.

Levstik, L.S. (2008) 'Building a sense of history'. In Levstik, L.S. and Barton, K.C. (eds) Researching History Education: Theory, method, and context. New York: Routledge, 30-60.

Levstik, L.S. and Barton, K.C. (2011) Doing History: Investigating with children in elementary and middle school. 4th ed. New York: Routledge.

Metzger, S. (2010) 'Magna Carta: Teaching medieval topics for historical significance'. History Teacher, 43 (3), 345-56. Online. www.societyforhistoryeducation.org/pdfs/Metzger.pdf (accessed 13 July 2020).

Nordgren, K. (2006). Vems är historien?: historia som medvetande, kultur och handling i det mångkulturella Sverige'. PhD thesis, Karlstad University.

Parkes, R.J. (2019) 'Developing your approach to history teaching'. In Allender, T., Clark, A. and Parkes, R.J. (eds) Historical Thinking for History Teachers: A new approach to engaging students and developing historical consciousness. Sydney: Allen and Unwin, 72-88.

Piaget, J. (1976) Framtidens skola: att förstå är att upptäcka. Stockholm: Forum.

Ricoeur, P. (1985) Time and Narrative, Vol. 2. Trans. McLaughlin, K. and Pellauer, D. Chicago: University of Chicago Press. 
Rosenzweig, R. and Thelen, D.P. (1998) The Presence of the Past: Popular uses of history in American life. New York: Columbia University Press.

Rudnert, J. (2019) 'Bland stenyxor och Tv-spel: om barn, historisk tid och när unga blir delaktiga i historiekulturen'. PhD thesis, Malmö University.

Rüsen, J. (2004). Berättande och förnuft: Historieteoretiska texter. Gothenburg: Daidalos.

Rüsen, J. (2005). History: Narration, interpretation, orientation. New York: Berghahn Books.

Rüsen, J. (2017) Evidence and Meaning: A theory of historical studies. Trans. Kerns, D. and Digan, K. New York: Berghahn Books.

Sandberg, K. (2018) 'Att lära av det förflutna: Yngre elevers förståelse för och motivering till skolämnet historia'. PhD thesis, Mälardalen University.

Sandahl, J. (2015) 'Medborgarbildning i gymnasiet: ämneskunnande och medborgarbildning i gymnasieskolans samhälls- och historieundervisning'. PhD thesis, Stockholm University.

Seixas, P. (1994) 'Students' understanding of historical significance'. Theory and Research in Social Education, 22 (3), 281-304. Online. https://doi.org/10.1080/00933104.1994.10505726

Seixas, P. (2017) 'A model of historical thinking'. Educational Philosophy and Theory, 49 (6), 593-605. Online. https://doi.org/10.1080/00131857.2015.1101363

Seixas, P. and Morton, T. (2013) The Big Six: Historical thinking concepts. Toronto: Nelson Education.

Stymne, A.-C. (2017) 'Hur begriplig är historien?: Elevers möjligheter och svårigheter i historieundervisningen i skolan'. PhD thesis, Historiska institutionen, Stockholm University.

Terizan, S.G. and Yeager E.A. (2007) "“That's when we became a nation": Urban Latino adolescents and the designation of historical significance'. Urban Education, 42 (1), 52-81. Online. https://doi.org/10.1177/0042085906294027

Thorp, R. and Persson, A. (2020) 'On historical thinking and the history educational challenge'. Educational Philosophy and Theory, 52 (8), 891-901. Online. https://doi.org/10.1080/ 00131857.2020 .1712550

VanSledright, B. (2002) 'Confronting history's interpretive paradox while teaching fifth graders to investigate the past'. American Educational Research Journal, 39, 1089-115. Online. https://doi.org/10.3102/000283120390041089

Wertsch, J.V. (2000) 'Is it possible to teach beliefs, as well as knowledge about history?' In Stearns, P.N., Seixas, P. and Wineburg, S. (eds) Knowing, Teaching, and Learning History: National and international perspectives. New York: New York University Press, 38-50.

Wineburg, S. (1991) 'Historical problem solving: A study of the cognitive processes used in the evaluation of documentary and pictorial evidence'. Journal of Educational Psychology, 83 (1), 73-87. Online. https://doi.org/10.1037/0022-0663.83.1.73

Wineburg, S. (2001) Historical Thinking and Other Unnatural Acts: Charting the future of teaching the past. Philadelphia: Temple University Press. 